\title{
Modelling the Dynamics of Government Finance on Bond Market Return in Nigeria
}

\author{
Olatunji Abdul Shobande \\ Department of Economics, Faculty of Social Sciences, University of Lagos, Lagos, Nigeria \\ Email: olatunji.shobande@yahoo.com
}

How to cite this paper: Shobande, O.A. (2018) Modelling the Dynamics of Government Finance on Bond Market Return in Nigeria. Theoretical Economics Letters, 8, 3438-3443.

https://doi.org/10.4236/tel.2018.815210

Received: October 22, 2018

Accepted: November 26, 2018

Published: November 29, 2018

Copyright $\odot 2018$ by author and Scientific Research Publishing Inc. This work is licensed under the Creative Commons Attribution International License (CC BY 4.0).

http://creativecommons.org/licenses/by/4.0/ c) (i) Open Access

\begin{abstract}
This study proposes a theoretical modeling approach for analyzing the impact of government finance on bond market return in Nigeria. The overall result shows that government finance affects not only the rate of return on asset issued by government but also the rate of return on private securities.
\end{abstract}

\section{Keywords}

Bond, Government Finance, Asset, Price Fluctuation, Nigeria

\section{Introduction}

The peculiarity and place of importance of government bonds in any financial system cannot be overemphasized. Amongst other uses, they play a predominant role in funds mobilization and serve as effective instrument for regulating the economy. The financial market securities are widely used as collateral in core government transactions, especially when resources are mobilized within an economy to meet government needs [1] [2]. Interestingly, studies have revealed a strong correlation between government finance and the bond market; for instance, Greenwood and [3], Fama [4] and Vayanos [5] found evidence that market dealers have limited risk bearing capacity, suggesting that an increase in long term government bond can predict the volatility in the bond market.

In Nigeria, the long term sustainability of government finances has been subject of immense debate, particularly with the presence of new treasury framework proposed by the Ministry of Finance to set fiscal framework towards counter cyclical financial stance, debt sustainability and domestic resource mobilization. As it were, the issuances of domestic government bonds and treasury bill along with government taxes remains the primary sources of finance available to the Nigerian government. This brings to fore the need to examine the relation- 
ship between government bonds and private securities. Thus, the relevance of this study is to help the fiscal and monetary authorities understand that the bond market offer an efficient vehicle for blending below-market capital within the guideline of fiscal strategy which have severe implication on the rate of return of private securities. The study therefore proposes a theoretical modeling strategy for analyzing the impact of government finance on bond market return in Nigeria. The outcome of the model will serve as policy ingredient to large number of audience such as the Central Bank of Nigeria (CBN), Ministry of Finance and the academia who are ambitious in providing solution to policy impotence in the Nigerian economy.

Following the introductory section, the paper is structured into four main sections. Section 2 provides a brief survey of existing literature while Section 3 addresses the theoretical building block of the model. Section 4 is the concluding remarks and policy outlook.

\section{Brief Survey of Literature}

The best way to begin this intellectual journey would be to probably ponder on the earlier Keynesian theoretical proposition that suggests the need to stimulate aggregate demand through expansionary fiscal policy (i.e. increase in government spending). To further complicate the issue, David Ricardo backed up the argument in Ricardian Equivalence curve by suggesting that the source of government finance does not really matter but the structure and composition of it expenditure (i.e. how government spends its money is a major concern) [6]. While this existing theoretical model and proposition appear robust and empirically appealing, it seems that the $18^{\text {th }}$ and $19^{\text {th }}$ century approaches to macroeconomics modelling have been challenged by recent expansion in the frontier of knowledge on many grounds.

Theoretically, the neoclassical approach developed over fifty years ago now provides different effect on macroeconomic consequence of government finance on bond market return, which is contrary to previous submission of Keynesian model [6] [7] [8]. In the view of attack on earlier thought, Friedman Milton [9] in his presidential address to the American Economic Association (AEA), cautioned that not too much should be expected from monetary policy, which reflects a contradiction to his argument that only money matters. Specifically, Milton further acknowledged that economists long ago have always neglected the possibility of monetary toolkit being constrained by government finance which in turn might have a feedback effect on private securities, a crucial element for monetary policy formation [10].

In 1981, Sargent and Wallace [11] attempt to search for the logic behind the puzzle visage by Friedman Milton in their article titled: Some Unpleasant Monetarist Arithmetic. Sargent and Wallace [11] presented a demand function for government finance with the assumption that seignorage can be earned on bonds as well as on the base money. Their results show that the demand for government bond is an increasing function of real rate of return on private 
securities. In 2002, Perotti estimated the effect of fiscal policy in OECD countries and confirmed that government spending shocks have significant effect on returns on private securities on one hand and net tax affect asset pricing on the other hand [6].

The various objections to Keynesian proposition on government finance-bond market returns nexus also reflected in varied results and policy responses submitted in academic conferences, seminar papers and working papers documented over the last twenty years. For instance, Nelson and Siegel [12]; Barro [13]: Benigno \& Michael [14]; Gagnon, Raskin, Remache and Sack [15]; Krshnamurthy \& Vessing-Jorgensen [16]; Hamilton and Wu [17]; Campbell, Evans, Fisher \& Justiniano [18], Liu \& Wei [8]; and Gilchrist, Sim \& Zakrajsek [19] all presented mix results regarding the possibility of government finance affecting bond market return in their various environment of studies.

A cursory look at these previous studies reviewed above shows there is a lacuna in the existing literature as information presented are insufficient and methodological deficiency can be observed. In particular, most of these studies pretend to show robust macro-econometric modelling relying heavily on Vector Autoregressive (VAR) to analyse the results providing more complicated results in the existing literature. The contribution of this study is thus simple. First, it provides serious objection to earlier studies' submission of Keynesian theoretical proposition that embraced expansionary policy and equally disagree with Richardian earlier assertion that the source of finance does not matter but how government spends its money is a major issue.

\section{Model}

\section{Building Block}

This study assumes that the balanced budget rule of $g_{t}=T_{t}$ holds and that government bond as well as private bond exist. Similarly, government expenditures are finance by a lump-sum tax at period $t$. It further assumed that taxing rule require $T_{t}=g_{t}+b\left[1-1 / R_{1 t}\right]$ where $b>0$ is a permanent level of borrowing.

Therefore, the representative agent is presented as:

$$
\max E_{0} \sum_{t=0}^{\infty} \beta^{t} u\left(c_{t}, \frac{b_{g t+1}}{R_{g t}}\right)
$$

Subject to

$$
c_{1}+\frac{b_{g t+1}}{R_{g t}}+p_{t} s_{t+1}+\tau_{1} \leq\left(p_{t}+d_{t}\right) s_{t}+b_{g t} \quad \text { [20] }
$$

we know that equilibrium consumption satisfies $c_{t}=d_{t}-g_{t}$. We also know that equilibrium $s_{t}=1$ and $g_{t}=\tau_{t}+\left(b_{g t+1}\right) /\left(R_{g t}\right)-b_{g t}$.

The Euler equations for this problem are

$$
u_{1}\left(c_{t}, \frac{b_{g t+1}}{R_{g t}}\right) p_{1}=\beta E_{t}\left\{u_{1}\left(c_{t+1}, \frac{b_{g t+1}}{R_{g t}}\right)\left(p_{t+1}+d_{t+1}\right)\right\}
$$




$$
\left[u_{1}\left(c_{t}, \frac{b_{g t+1}}{R_{g t}}\right)+u_{2}\left(c_{t}, \frac{b_{g t+1}}{R_{g t}}\right)\right] R_{g t}^{-1}=\beta E_{t}\left\{u_{1}\left(c_{t+1}, \frac{b_{g t+2}}{R_{g t+1}}\right)\right\}
$$

Now consider a change in $b_{g t+1}$ that leaves $\left(c_{t}, g_{t}\right)$ unchanged and hence requires an adjustment in taxes. Moreover, assume that $c_{t+1}, g_{t+1}, b_{t+2}, R_{g t+1}$ also remain unchanged so that we can analyze the effect of $b_{g t+1}$ upon $R_{g t}$ and $p_{t}$ (This can always be done by suitable choice of $\tau_{1}$ and $\tau_{t+1}$.)

Differentiating the Euler equations we get

$$
\begin{gathered}
p_{1} u_{12}(\cdot)\left(R_{g t}^{-1}-b_{g t+1} R_{g t}^{-2} \frac{\mathrm{d} R_{g t}}{\mathrm{~d} b_{g t+1}}\right)+u_{1}(\cdot) \frac{\mathrm{d} p_{t}}{\mathrm{~d} b_{g t+1}}=0 \\
\left(u_{12}+u_{22}\right)\left(R_{g t}^{-1}-b_{g t+1} R_{g t}^{-2} \frac{\mathrm{d} R_{g t}}{\mathrm{~d} b_{g t+1}}\right)=\frac{\mathrm{d} p_{t}}{\mathrm{~d} b_{g t+1}} R_{g t}^{-2}\left(u_{1}+u_{2}\right)
\end{gathered}
$$

Rearranging the equation gives;

$$
\frac{b_{g t+1}}{R_{g t}} \frac{\mathrm{d} p_{t}}{\mathrm{~d} b_{g t+1}}=\frac{b_{g t+1}\left(u_{12}+u_{22}\right)}{b_{g t+1}\left(u_{12}+u_{22}\right)+\left(u_{1}+u_{2}\right)}
$$

For fixed $c$, define $f(b / R) \equiv u_{1}(c, b / R)+u_{2}(c, b / R)$. The previous formula for the elasticity of the return on government bonds can be written as

$$
\frac{b}{R} \frac{\mathrm{d} R}{\mathrm{~d} b}=\frac{b f^{\prime}\left(\frac{b}{R}\right)}{b f^{\prime}\left(\frac{b}{R}\right)+f\left(\frac{b}{R}\right)}
$$

If we assume that $f^{\prime}\left(\frac{b}{R}\right)=u_{12}+u_{22}<0$, it follows that, if $\left(\frac{\mathrm{d} R}{\mathrm{~d} b}\right) \frac{b}{R} \geq 0$, then $(\mathrm{d} R / \mathrm{d} b) \cdot b / R \geq 1$.

Now, the first equation of the system can be written (neglecting sub-indexes) as

$$
\frac{\mathrm{d} p}{\mathrm{~d} b}=-u_{1}^{-1}\left\{p u_{12} R^{-1}\left(1-\frac{b}{R} \frac{\mathrm{d} R}{\mathrm{~d} b}\right)\right\}
$$

If $(\mathrm{d} R / \mathrm{d} b) \cdot b / R \geq 1 \quad$ and $\quad u_{12}>0, \mathrm{~d} p / \mathrm{d} b \geq 0$. If $(\mathrm{d} R / \mathrm{d} b) \cdot b / R<0 \quad$ and $u_{12}>0$ then $\mathrm{d} p / \mathrm{d} b<0$.

Now as $\left(p_{t+1}+d_{t+1}\right)=-\operatorname{sign}[(\mathrm{d} p / \mathrm{d} b) \cdot(\mathrm{d} R / \mathrm{d} b)]$. For the two cases described above, we have that $\mathrm{d} R_{p t} / \mathrm{d} R_{g t}<0$ notice that if $u_{12}=0$, changes in $b_{g t+1}$ do not affect the rate of return on private securities.

\section{Concluding Remarks}

The study examines the relationship between government finance and return on private securities using a modeling approach to identify the different transmission channel and which tax-debt combination is used in government finance. Accordingly, this does not only affect the rate of return of asset issued by government but also rate of return on private securities. In all, the degree of government finance cum bond market return varies, since the direction of the effect depends on the government utility function which is dictated by it budget constraints in different periods. 
While a growing body of existing empirical studies suggests the possibility of government and private securities to create money for the economy, the macroeconomic model demonstrated above warns that attempt to source finance from domestic economy might have the tendency to frustrate and crowd out returns on bond markets. This is obvious since fiscal discipline is a matter of institutional setting and the fiscal objective of the government. This has always been adopted as part of monetary policy despite the quest for policy mix for effective coordination.

\section{Conflicts of Interest}

The author declares no conflicts of interest regarding the publication of this paper.

\section{References}

[1] Modigliani, F. and Miller, M.H. (1958) Cost of Capital, Corporation Finance, and the Theory of Investment. America Economic Review, 48, 261-297.

[2] Gao, J., Jin, J. and Thompson, J. (2018) The Impact of Government Debt Supply on Bond Market Liquidity: An Empirical Analysis of Canadian Market. Bank of Canada, Working Paper. https://doi.org/10.2139/ssrn.3176181

[3] Barro, R.J. (1974) Are Government Bonds Net Wealth? Journal of Political Econo$m y$, 82, 1095-1117. https://doi.org/10.1086/260266

[4] Fama, E. (1976) Foundation of Finance: Portfolio Decisions and Securities Prices. Basic Books, New York.

[5] Vayanos, D. and Wang, J. (2013) Market Liquidity: Theory and Empirical Evidence. Handbook of the Economics of Finance, 2, 1289-1361. https://doi.org/10.1016/B978-0-44-459406-8.00019-6

[6] Blanchard, O. and Perotti, R. (1999) An Empirical Characterisation of the Dynamic effects of Change in Government Spending and Taxes on Output. NBER Working Paper Series, No. 7269.

[7] Lucas, R. and Nancy, I.S. (1983) Optimal Monetary Policy in an Open Economy without Capital. Journal of Monetary Economics, 12, 55-93.

https://doi.org/10.1016/0304-3932(83)90049-1

[8] Liu, C. and Wei, M. (2012) Term Structure Modelling with Supply Factors and the Federal Reserve's Large Scale Asset Purchases Programs. Finance and Economics Discussion Series. Federal Reserve's Board, Washington DC.

[9] Friedman, M. (1968) The Role of Monetary Policy. The American Economic Review, 58, 1-17. https://www.jstor.org/stable/1831652

[10] Blanchard, O. and Alessandro, M. (1994) The Debt Burden and Debt Maturity. American Economic Review, 84, 309-319.

[11] Sergent, T.J. and Wallace, N. (1981) Some Unpleasant Monetarist Arithmetic. Federal Reserve's Quarterly Review. Banks of Minneapolis, 5, 1-18.

[12] Nelson, C.R. and Siegel, A. (1987) Parsimonous Modelling of Yield Curves. Journal of Business, 60, 474-489. https://doi.org/10.1086/296409

[13] Barro, R.J. (1997) Optimal Funding Policy. In: King and Calvo, Eds., The Debt Burden and Its Consequence for Monetary Policy, Macmillian, London. 
[14] Benigno, P. and Michael, W. (2003) Optimal Monetary and Fiscal Policy: A Linear Quadratic Approach. NBER Macroeconomic Annual, NBER Working Paper No. 9905.

[15] Gagnon, J., Raskin, M., Ramache, J. and Sack, B. (2011) The Financial Market Effects of the Federal Reserve's Large Scale Asset Purchases. International Journal of Central Banking, 7, 3-43.

[16] Krishnamurthy, A. and Vissing-Jorgensen, A. (2011) Aggregate Demand for Treasury Debt, Working Paper.

[17] Hamilton, J.D. and Wu. J.C. (2012) The Effectiveness of Alternative Monetary Policy Tool in Zero Lower Bond. NBER Working Paper, No. 16956.

[18] Campbell, J., Evans, C., Fisher, D.M. and Justiniano, A. (2012) Macroeconomic Effects of Federal Reserve Forward Guidance. Brookings Paper on Economic Activity.

[19] Gilchrist, S., Sim, J.W and Zakrajsek, A.M (2013) Misallocation and Financial Market Friction: Some Direct Evidence from Dispersion in Borrowing Costs. Review of Economics Dynamics, 16, 159-176. https://doi.org/10.1016/j.red.2012.11.001

[20] Sargent, T.J. (1987) Dynamic Macroeconomic Theory. Harvard University Press, Cambridge, MA. 